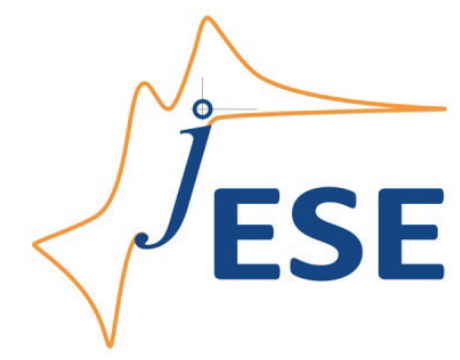

Open Access : : ISSN 1847-9286

www.jESE-online.org

Original scientific paper

\title{
Silver ion recognition using potentiometric sensor based on recently synthesized isoquinoline-1,3-dione derivatives
}

\author{
AJAR KAMAL, RAJIV KUMAR PURI, RAGHU RAJ, VIPAN KUMAR and RAKESH KUMAR \\ MAHAJAN
}

Department of Chemistry, UGC-Centre for Advanced Studies, Guru Nanak Dev University, Amritsar143005, India

${ }^{\square}$ Corresponding Author: E-mail: rakesh chem@yahoo.com; Tel.: +91-183-2502223; Fax +91-183-2258820

Received: March 27, 2012; Revised: May 22, 2012; Published: August 30, 2012

\begin{abstract}
The four derivatives of isoquinoline-1,3-dione based on 8-lactum (I-IV), have been explored as neutral ionophores for preparing poly(vinylchloride) based polymeric membrane electrodes (PME) selective to silver(I) ions. The addition of sodium tetraphenylborate (NaTPB) and dioctylsebacate (DOS) as a plasticizer was found to improve the performance of ion selective electrodes. The best performance was obtained with PME-1 based on ionophore I having composition: ionophore $(9.2 \mathrm{mg})$, PVC (100.1 mg), DOS (201.1 mg) and NaTPB $(1.5 \mathrm{mg})$ in $5 \mathrm{~mL}$ tetrahydrofuran. The electrode response was linear with Nernstian slope of $58.44 \mathrm{mV} /$ decade in the concentration range of $1.0 \times 10^{-1} \mathrm{M}$ to $5.0 \times 10^{-6} \mathrm{M}$ and detection limit of $5.83 \times 10^{-6} \mathrm{M}$. It performs satisfactorily over wide $\mathrm{pH}$ range of 1.0-5.5. The proposed sensor can be used over a period of more than three months without any significant drift in potential and shows good selectivity to silver(I) ion over a number of cations especially with no interference of mercury(II) ions. Sharp end point was obtained when the sensor was used as an indicator electrode for the potentiometric titration of silver $(I)$ ions with chloride ions and therefore this electrode (PME-1) could be used for quantitative determination of silver(I) ion in synthetic water, silver foil and dental amalgam samples.
\end{abstract}

\section{Keywords}

Isoquinoline-1, 3-diones, Silver(I) ion, Potentiometric sensors, Selectivity, Indicator Electrode. 


\section{Introduction}

Silver has wide commercial importance in photography, medicine, optics, electronics, and production of currency, jewelry and silverware as well as high capacity silver-zinc and silvercadmium batteries [1,2]. Because of its antibacterial properties, silver compounds have been used to disinfect drinking water and water for recreational purposes, in dental, pharmaceutical, antibacterial, anti-HIV preparations and implanted prostheses [3]. Soluble silver salts are lethal and slowly absorbed by body tissues, with consequent bluish or blackish skin pigmentation (argyria), and causes severe corneal injury if liquid comes in contact with the eyes. It may produce other toxic effects including kidney, eye, lung, liver and brain damage as well as change in blood cells. Metallic silver, however, appears to pose a minimal risk to health [4]. It has been found that an excess of silver is toxic to fish and micro-organisms at a concentration as low as $0.17 \mu \mathrm{g} \mathrm{L}^{-1}$ [3]. It is therefore crucial to closely monitor the activity of silver in the environment. There exist several techniques for silver metal ion determination, such as inductively coupled plasma atomic emission spectrometry [5,6], inductively coupled plasma mass spectrometry $[7,8]$ and flame absorption spectrometry $[9,10]$, but these techniques are normally time consuming, involving sample manipulation, and they are relatively expensive. Ion-selective electrodes (ISEs) have been established for many years as powerful analytical tools. Carrier-based ISEs have found widespread use for the direct determination of various ionic species in complex samples [11-15]. The ISE is an ion analysis technique that provides unique characteristics such as selectivity, good precision, simplicity and low cost [16-19]. ISEs have been successfully applied for trace analysis of ions of environmental and physiological importance [20-22]. The determination of silver(I) ions in presence of mercury(II) ions is often a challenging job. Silver selective potentiometric sensors based on ion carriers like podands, crown ethers and calixarenes derivatives have been reported [2,23-32]. In addition, bis-pyridinetetramide macrocyclic [33], bis-dialkyldithiophosphate derivative [34] and 0,0,0-trialkylphosphorothioates [35] have been reported as effective ionophores to construct silver(I) ion selective electrodes. These ionophores are generally hampered with mercury(II) ions interference. In this work, we report the use of isoquinoline-1,3dione derivatives based on $\beta$-lactum as a highly selective neutral ion carrier for detection of silver(I) ions using membrane ion selective electrodes. The need for highly sensitive and selective determination of silver(I) ions arises from silver's economic value and the toxicity toward human beings. In present work, an attempt has been made to improve the sensitivity and selectivity of silver(I) ions ISE towards various secondary ions particularly mercury(II) ions. The electrochemical selectivity for various metal ions, the effect of membrane components, internal solution and $\mathrm{pH}$ of sample solution on the electrode response was investigated. Further, the electrode was also used as indicator electrode in titration experiments.

\section{Experimental}

\subsection{Materials}

All reagents used were of analytical grade, and doubly distilled deionised water was used to prepare solutions. All isoquinoline-1,3-dione derivatives i.e. (4RS,4aSR)-4-[(SR)phenyl(p-tolylamino)methyl)-4a,7,8,8a-tetrahydro-4H-isoquinoline-1,3-dione [I], (4RS,4aSR)-4-[(SR)p-tolyl(p-tolylamino)methyl)-4a,7,8,8a-tetrahydro-4H-isoquinoline-1,3-dione [II], (4RS,4aSR)-4-[(SR)4-chloro-phenyl(ptolylamino)methyl]-4a,7,8,8a-tetrahydro-4H-isoquinoline-1,3-dione [III], (4RS,4aSR)-4-[(SR)4-chlorophenylamino(p-tolyl)methyl]-4a,7,8,8a-tetrahydro-4H-isoquinoline 1,3-dione [IV] were synthesied as 
reported in literature [36] and they are shown in Fig. 1. The plasticizers bis-2-ethylhexylsebacate (DOS), bis-2-ethylhexylphthalate (DOP), bis-2-ethylhexyladipate (DOA), dibutylphthalate (DBP) and tributylphosphate (TBP) and high molecular weight poly(vinylchloride)(PVC) were used as received from Fluka. Anion excluder sodium tetraphenylborate (NaTPB) was obtained from Aldrich while silver nitrate and other metal nitrates received from Merck were used without any further purification.

\subsection{Preparation of PVC membrane}

The general procedure for preparation of PVC membrane was to mix thoroughly PVC, plasticizer, additive and varying amount of isoquinoline-1,3-dione based ionophore in about $5 \mathrm{~mL}$ of tetrahydrofuran. Mixture was shaken vigorously and clear solution was poured into petri-dish (50 $\mathrm{mm}$ diameter). Solvent was allowed to evaporate at room temperature. The resulting membrane of $0.4 \mathrm{~mm}$ thickness was cut to size, attached to PVC tube with help of PVC glue and conditioned with metal ion solution $\left(10^{-2} \mathrm{M}\right)$ for about 24 hours till it gave reproducible and stable potential.<smiles>Cc1ccc(C(Nc2ccc(Cl)cc2)C2C(=O)NC(=O)C3CCC=CC32)cc1</smiles>

(I)<smiles>Cc1ccc(NC(c2ccc(C)cc2)C2C(=O)NC(=O)C3CCC=CC32)cc1</smiles>

(III)<smiles>Cc1ccc(NC(c2ccccc2)C2C(=O)NC(=O)C3CCC=CC32)cc1</smiles>

(II)<smiles>Cc1ccc(NC(c2ccc(Cl)cc2)C2C(=O)NC(=O)C3CCC=CC32)cc1</smiles>

(IV)

Figure 1. Structures of isoquinoline-1,3-dione receptors I-IV

\subsection{EMF measurements}

Silver/silver chloride electrodes with $3 \mathrm{M} \mathrm{KCl}$ as salt bridge were used as internal and external reference electrodes. The electrochemical cell assembly used for the study was:

$$
\begin{array}{l|l|c|c|c|c|c}
\mathrm{Ag}-\mathrm{AgCl} & 3 \mathrm{M} \mathrm{KCl} & \begin{array}{c}
1.0 \times 10^{-2} \mathrm{M} \\
\mathrm{AgNO3}
\end{array} & \begin{array}{c}
\mathrm{PVC} \\
\text { membrane }
\end{array} & \begin{array}{c}
\text { Test } \\
\text { Solution }
\end{array} & 3 \mathrm{M} \mathrm{KCl} & \mathrm{Ag}-\mathrm{AgCl}
\end{array}
$$

All the measurements of electrode potential were made with EQUIPTRONICS MODEL EQ-602 potentiometer. The $\mathrm{pH}$ measurements were made using Elico LI MODEL-120 pH meter. 


\section{Results and Discussion}

\subsection{Potentiometric response for multiple-ions using polymeric membrane electrodes}

In preliminary experiments, different PVC-based ion selective membrane sensors, using isoquinoline-1,3-dione based receptor I as ion carrier, were prepared by mixing $100.1 \mathrm{mg}$ PVC, $201.1 \mathrm{mg}$ DOS and $9.2 \mathrm{mg}$ receptor I. Membranes so prepared were conditioned with $10^{-2} \mathrm{M}$ solution of different ions for 24 hours. Their potential responses were noted against $10^{-1} \mathrm{M}$ to $10^{-8} \mathrm{M}$ solutions of respective analyte ions to determine their potentiometric response for different metal ions (Figure 2). Silver(I) ions were found to give better response in terms of slope, working concentration range and lower detection limit as compared to other metal ions. Results obtained indicate that electrode based on receptor I has preferential affinity for silver(I) ions and it can be employed as an ionophore for the preparation of silver(I) ion selective electrodes. The preferential affinity of receptor I for silver(I) ions can be due to the presence of nitrogen and oxygen as donor atoms.

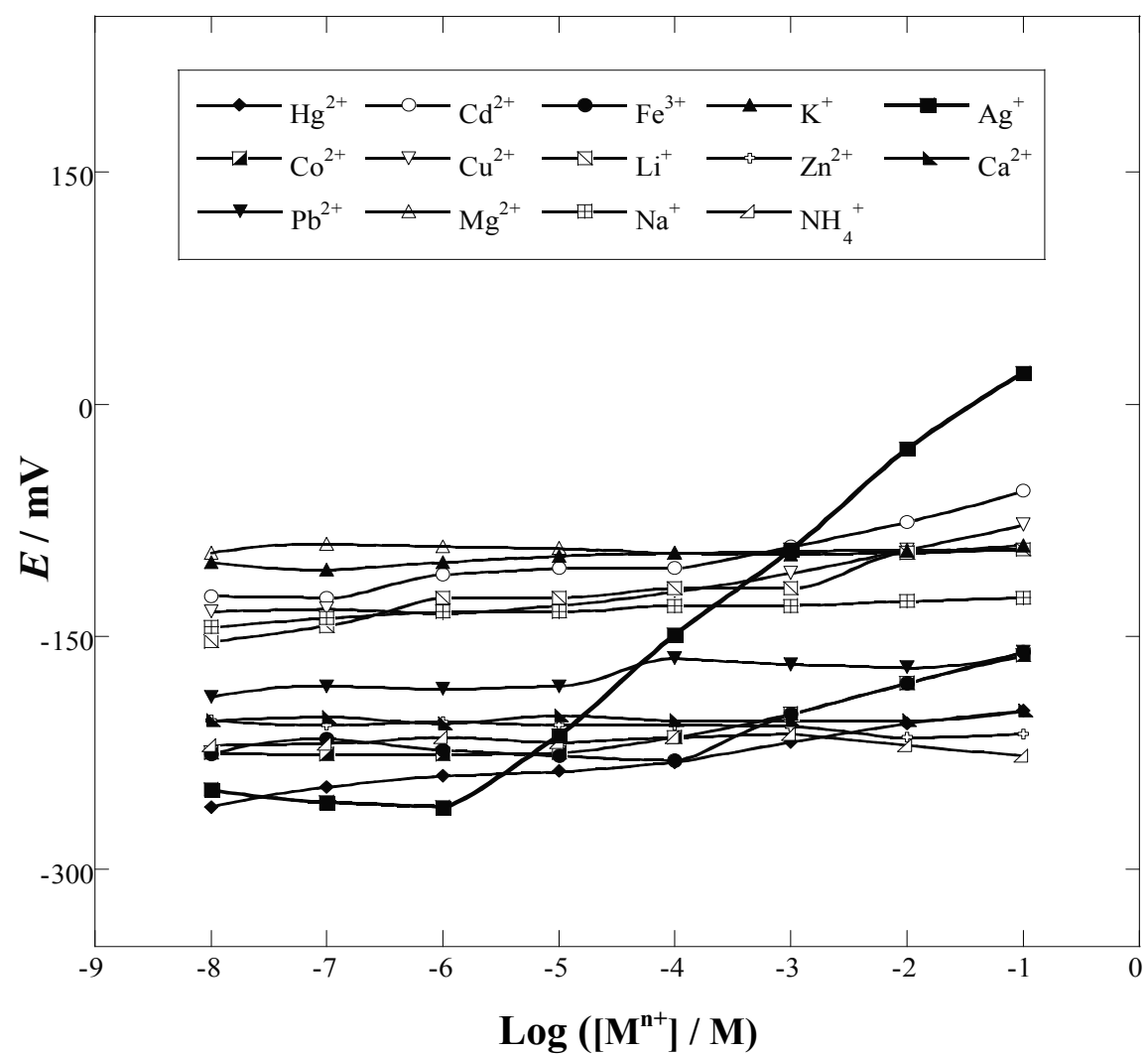

Figure 2. Potentiometric response of polymeric membrane electrodes based on isoquinoline-1 3-dione receptor I for various metal ions

\subsection{Potential response for silver(I) ions using polymeric membrane electrodes}

Based on the results obtained from the preliminary investigation with receptor I, it was decided to employ isoquinoline-1,3-dione based receptors I-IV as ion carrier for the preparation of silver(I) ion selective electrodes. Response curves of polymeric membrane electrodes PMEs 1-4 incorporating receptors I-IV, respectively, as ion carriers are shown in Fig. 3. The composition and the response characteristics obtained for the polymeric membrane electrodes PMEs 1-4 are shown in Table 1. 
Table 1. Composition and response characteristics of silver(I) ion selective electrodes based on isoquinoline-1,3-dione receptors I-IV as ionophores

\begin{tabular}{|c|c|c|c|c|c|c|c|c|}
\hline S. No. & $\begin{array}{c}\text { PVC, } \\
\text { mg }\end{array}$ & $\begin{array}{l}\text { Plasticizer, } \\
\text { mg }\end{array}$ & $\begin{array}{c}\text { NaTPB, } \\
\text { mg }\end{array}$ & $\begin{array}{c}\text { lonophore, } \\
\text { mg }\end{array}$ & $\begin{array}{c}\text { Internal } \\
\text { Solution, M }\end{array}$ & Linear Range, $M$ & $\begin{array}{l}\text { Detection } \\
\text { Limit , M }\end{array}$ & $\begin{array}{c}\text { Slope, } \\
\mathrm{mV} \mathrm{dec}^{-1}\end{array}$ \\
\hline PME-1 & 100.1 & 201.1 DOS & 1.5 & 9.21 & $1.0 \times 10^{-2}$ & $1.0 \times 10^{-1}-5.0 \times 10^{-6}$ & $5.83 \times 10^{-6}$ & 58.44 \\
\hline PME-2 & 100.6 & 199.8 DOS & 1.5 & $9.0 \mathrm{II}$ & $1.0 \times 10^{-2}$ & $1.0 \times 10^{-1}-1.0 \times 10^{-5}$ & $9.54 \times 10^{-6}$ & 52.72 \\
\hline PME-3 & 100.0 & 201.7 DOS & 1.6 & $9.2 \mathrm{III}$ & $1.0 \times 10^{-2}$ & $1.0 \times 10^{-1}-1.0 \times 10^{-5}$ & $1.15 \times 10^{-5}$ & 49.62 \\
\hline PME-4 & 100.3 & 199.6 DOS & 1.6 & $8.9 \mathrm{IV}$ & $1.0 \times 10^{-2}$ & $1.0 \times 10^{-1}-1.0 \times 10^{-5}$ & $1.07 \times 10^{-5}$ & 67.47 \\
\hline PME-5 & 100.2 & 201.0 DOS & 1.5 & 9.21 & $1.0 \times 10^{-3}$ & $1.0 \times 10^{-1}-1.0 \times 10^{-5}$ & $1.01 \times 10^{-5}$ & 53.20 \\
\hline PME-6 & 100.0 & 201.2 DOS & 1.5 & 9.21 & $1.0 \times 10^{-1}$ & $1.0 \times 10^{-1}-5.0 \times 10^{-5}$ & $8.12 \times 10^{-5}$ & 44.96 \\
\hline PME-7 & 100.0 & 201.0 DOS & 1.5 & 7.01 & $1.0 \times 10^{-2}$ & $1.0 \times 10^{-1}-1.0 \times 10^{-5}$ & $3.16 \times 10^{-5}$ & 44.50 \\
\hline PME-8 & 100.5 & 200.2 DOS & 1.6 & 5.21 & $1.0 \times 10^{-2}$ & $1.0 \times 10^{-1}-1.0 \times 10^{-5}$ & $1.07 \times 10^{-5}$ & 49.09 \\
\hline PME-9 & 101.0 & 201.5 DOS & 1.5 & 3.21 & $1.0 \times 10^{-2}$ & $1.0 \times 10^{-1}-5.0 \times 10^{-6}$ & $6.45 \times 10^{-6}$ & 27.52 \\
\hline PME-10 & 100.4 & 200.7DOS & 3.0 & 9.01 & $1.0 \times 10^{-2}$ & $1.0 \times 10^{-1}-1.0 \times 10^{-5}$ & $1.05 \times 10^{-5}$ & 50.31 \\
\hline PME-11 & 100.8 & 200.3 DOS & - & 9.11 & $1.0 \times 10^{-2}$ & $1.0 \times 10^{-1}-5.0 \times 10^{-6}$ & $4.36 \times 10^{-6}$ & 38.09 \\
\hline PME-12 & 100.0 & 200.0 DBP & 1.5 & $9.2 \quad 1$ & $1.0 \times 10^{-2}$ & $1.0 \times 10^{-1}-1.0 \times 10^{-5}$ & $1.90 \times 10^{-5}$ & 29.25 \\
\hline PME-13 & 100.0 & 200.3 DOA & 1.5 & 9.21 & $1.0 \times 10^{-2}$ & $1.0 \times 10^{-1}-5.0 \times 10^{-6}$ & $8.91 \times 10^{-5}$ & 71.86 \\
\hline PME-14 & 99.9 & 200.1 TBP & 1.6 & 9.01 & $1.0 \times 10^{-2}$ & $1.0 \times 10^{-1}-1.0 \times 10^{-5}$ & $5.01 \times 10^{-6}$ & 77.56 \\
\hline PME-15 & 100.6 & 201.4 DOP & 1.6 & 9.11 & $1.0 \times 10^{-2}$ & $1.0 \times 10^{-1}-1.0 \times 10^{-5}$ & $1.77 \times 10^{-5}$ & 17.39 \\
\hline
\end{tabular}

The silver(I) ion ISEs PME-2, PME-3 and PME-4 exhibited Nernstian slopes of 52.72, 49.62 and $67.47 \mathrm{mV} \mathrm{dec}^{-1}$, respectively, in the concentration range of $1.0 \times 10^{-1} \mathrm{M}$ to $1.0 \times 10^{-5} \mathrm{M}$ silver(I) ions and produced lower detection limits of the order of $9.54 \times 10^{-6} \mathrm{M}, 1.15 \times 10^{-5} \mathrm{M}$ and $1.07 \times 10^{-5} \mathrm{M}$, respectively. Electrode PME-1 based on receptor I shows Nernstian slope of $58.44 \mathrm{mV} \mathrm{dec}{ }^{-1}$ over concentration range of $1.0 \times 10^{-1} \mathrm{M}$ to $5.0 \times 10^{-6} \mathrm{M}$ silver(I) ions with $5.83 \times 10^{-6} \mathrm{M}$ as lower detection limit.

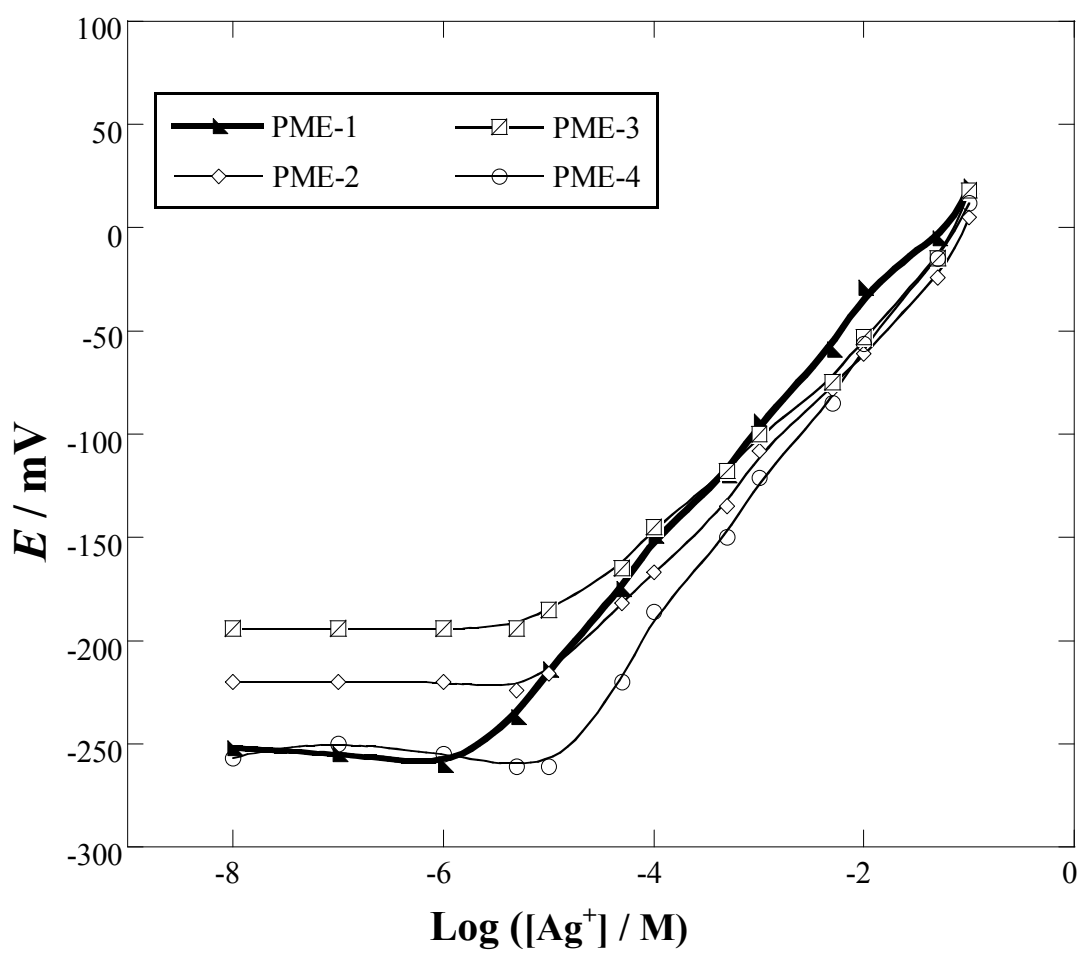

Figure 3. Potentiometric responses of silver(I) selective polymeric membrane electrodes based on isoquinoline-1,3-dione receptors I-IV as ionophores 


\subsection{Effect of internal solution}

The effect of the concentration of internal solution on the potential response of the PME-1, PME-5 and PME- 6 for silver(I) ion based on receptor I was studied. The internal solution concentration of silver(I) ion was varied from $1.0 \times 10^{-1} \mathrm{M}$ to $1.0 \times 10^{-3} \mathrm{M}$ and the potential response of PME-1 was observed as shown in Table 1. The concentration of internal solution has been found to affect the slope and the working range of the electrode. Further, it was found that the best results, in terms of Nernstian slope and the working concentration range, were obtained with the internal solution of concentration $1.0 \times 10^{-2} \mathrm{M}$. Thus, $1.0 \times 10^{-2} \mathrm{M}$ solution was found to be quite appropriate for the smooth functioning of the proposed polymeric electrode PME-1.

\subsection{Effect of ionophore content}

The influence of the ionophore content on the response behavior of silver(I) ion selective electrode incorporating receptor I as an ion carrier was studied by preparing membrane electrodes PME-1, PME-7, PME-8 and PME-9, using varying amount of receptor I (Table 1). Polymeric membrane electrode PME-1 containing $9.2 \mathrm{mg}$ of receptor I exhibited Nernstian slope of $58.44 \mathrm{mV} \mathrm{dec}^{-1}$ over the wide concentration range of $1.0 \times 10^{-1} \mathrm{M}$ to $5.0 \times 10^{-6} \mathrm{M}$ with lower detection limit of $5.83 \times 10^{-6} \mathrm{M}$, whereas, polymeric membrane electrodes PME-7, PME-8 and PME-9, containing $7.0 \mathrm{mg}, 5.2 \mathrm{mg}$ and $3.2 \mathrm{mg}$ of receptor $\mathrm{l}$, exhibited sub-Nernstian slopes over comparatively narrow concentration range with lower detection limit of $3.16 \times 10^{-5} \mathrm{M}, 1.07 \times 10^{-5} \mathrm{M}$ and $6.45 \times 10^{-6} \mathrm{M}$, respectively (Table 1). The best result was obtained in case of PME-1 containing $9.2 \mathrm{mg}$ content of receptor $\mathrm{I}$.

\subsection{Effect of additive content}

The presence of lipophilic negatively charged additive improve the potentiometric behavior of cation-selective electrodes by reducing ohmic resistance, increasing the membrane sensitivity in case of ionophore whose extraction capability is poor [37] and by catalyzing the exchange kinetics [38]. Thus the presence of lipophilic negatively charged additive improve the response behavior and selectivity of ion selective electrodes $[37,39,40]$. In our study sodium tetra phenyl borate (NaTPB) was incorporated as an additional membrane component (Table 1). Polymeric membrane electrodes PME-1 and PME-10 were prepared by using $1.5 \mathrm{mg}$ and $3.0 \mathrm{mg}$ of NaTPB and PME-11 was prepared without any additive (NaTPB). Response characteristics for the polymeric membrane electrodes PME-1, PME-10 and PME-11 incorporating varying amount of NaTPB are given in Table 1. It is clear from Table 1 that $1.5 \mathrm{mg} \mathrm{NaTPB}$ is the optimal content required for proper functioning of receptor I based silver(I) ion selective electrode. It may be due to the fact that $1.5 \mathrm{mg}$ of NaTPB is the appropriate amount for the charge compensation of counter ion in the membrane and thus facilitates the process of the ion charge transduction. On the other hand, PME-11 which contains no lipophilic additive shows sub-Nernstian slope. That may be due to the presence of anionic impurities within the polymer matrix [41].

\subsection{Effect of nature of plasticizer}

The dielectric constant of the membrane phase, the mobility of ionophore molecules and the state of ligands are dependent on the nature of the plasticizer incorporated in the membrane $[14,42]$. The selectivity and the sensitivity of the selective electrode strongly depend on the membrane composition and the nature of plasticizer used [11,43]. The effect of plasticizer on the potential response of silver(I) ion ISE incorporating isoquinoline-1,3-dione receptor I as an ion carrier was studied by preparing different membrane sensors containing plasticizer such as DOS, 
DBP, DOA, TBP, DOP and the results are summarized in Table 1. The electrodes PME-13 and PME-14, prepared by incorporating DOA and TBP, exhibited super-Nernstian slopes (71.86, $77.56 \mathrm{mV} \mathrm{dec}^{-1}$ ), while DBP and DOP incorporating electrodes PME-12 and PME-15 exhibited sub-Nernstian response $\left(29.25,17.39 \mathrm{mV} \mathrm{dec}^{-1}\right)$. The response of membrane sensor PME-1 incorporating DOS as a plasticizer was found to be better in terms of Nernstian slope of $58.44 \mathrm{mV} \mathrm{dec}^{-1}$ and wide linear concentration range of $1.0 \times 10^{-1} \mathrm{M}$ to $5.0 \times 10^{-6} \mathrm{M}$.

\subsection{Effect of $\mathrm{pH}$}

The potential response of an ion selective electrode is affected by $\mathrm{pH}$ of the analyte ion solution. The $\mathrm{pH}$ dependence of the polymeric membrane electrodes PMEs 1-4 containing receptors I-IV as ionophores were examined at $1.0 \times 10^{-2} \mathrm{M}$ concentration of silver(I) ions as shown in Fig. 4. The $\mathrm{pH}$ values were adjusted using conc. nitric acid and hexamine and the potential was measured after each addition. The electrode potential for all four electrodes remained constant over a $\mathrm{pH}$ range 1.0 to 5.5, which was the working $\mathrm{pH}$ range of the proposed silver(I) ion electrode. At lower $\mathrm{pH}<1$ deviation in potential may be due to the hydrogen error of the indicator electrode, and the sharp change at higher $\mathrm{pH}$ values may be due to the formation of some hydroxyl complexes of the charge transport process by the membrane, thereby causing interference.

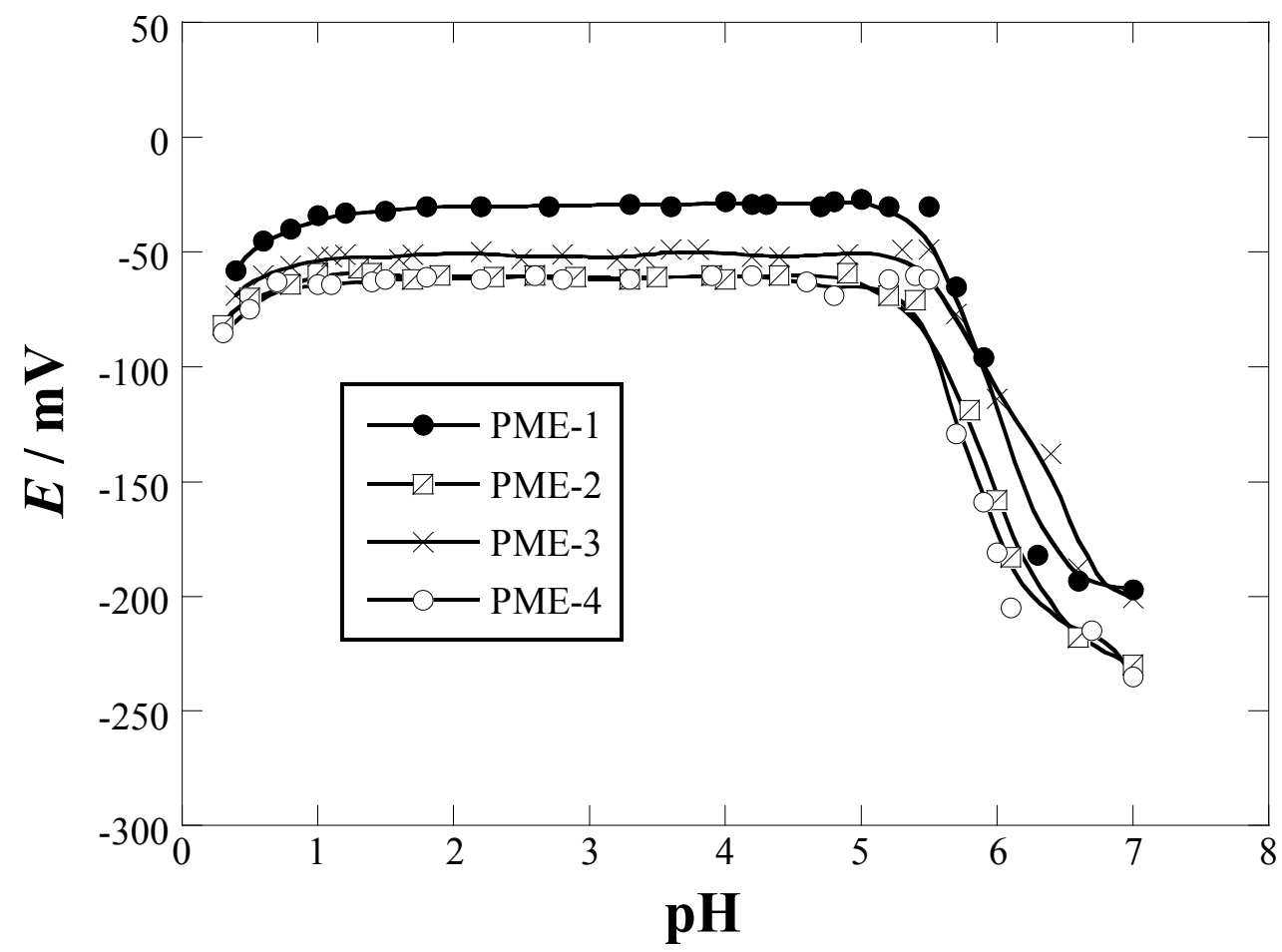

Figure 4. Effect of $\mathrm{pH}$ on potential response of silver(I) ion selective polymeric membrane electrodes PME 1-4 based on isoquinoline-1,3-dione receptors I-IV as ionophores

\subsection{Response time and life time of proposed electrode}

The response time of an ion selective electrode is the average time required for attaining the equilibrium value of the potential. In this study the practical response time was recorded from lower to higher successive concentrations of silver $(\mathrm{I})$ ions solutions $\left(10^{-5} \mathrm{M}\right.$ to $\left.10^{-1} \mathrm{M}\right)$. A potential versus time trace for electrode PME-1 is shown in Fig. 5. It is evident that the electrode reached the equilibrium response in a very short time of less than 12 seconds and no change was observed up to 5 minutes. The life time of the present electrode was more than three months and electrode 
potentials were reproducible. After more than three months the selectivity and sensitivity of polymeric membrane started degrading. It may be due to the leaching out of ionophores from the membrane. The response time of the proposed sensor PME-1 is compared with the best silver(I) ion-selective electrodes reported earlier in literature (Table 2). It is clear from Table 2 that proposed electrode is better as compared to other reported electrodes in regard to Nernstian slope, lower detection limit, $\mathrm{pH}$ range and working concentration range.

Table 2. A comparative study of the proposed silver(I) ion selective electrodes with previously reported ion selective electrodes for silver(I) ion

\begin{tabular}{|c|c|c|c|c|c|c|}
\hline Ionophore & Linear Range, $\mathbf{M}$ & $\begin{array}{l}\text { Detection } \\
\text { Limit, } \mathrm{M}\end{array}$ & $\begin{array}{c}\mathrm{pH} \\
\text { Range }\end{array}$ & $\begin{array}{c}\text { Slope, } \\
\mathrm{mV} \mathrm{dec}^{-1}\end{array}$ & $\begin{array}{c}\text { Response } \\
\text { time, } s\end{array}$ & $\begin{array}{l}\text { Ref. } \\
\text { No. }\end{array}$ \\
\hline $\begin{array}{l}\text { Schiff-base }\left(\mathrm{N}^{2} \mathrm{E}, \mathrm{N}^{2^{\prime}} \mathrm{E}\right)-\mathrm{N}^{2}, \mathrm{~N}^{2^{\prime}}- \\
\text { bis(thiophen-2-ylmethy- } \\
\text { lene)-1,1-biNaphthyl-2,2'-di- } \\
\text { amine. }\end{array}$ & $1.0 \times 10^{-7}-1.0 \times 10^{-2}$ & $-{ }^{a}$ & $2.0-6.0$ & 57.40 & 9 & [44] \\
\hline Calix[4]arene. & $1.0 \times 10^{-5}-1.0 \times 10^{-2}$ & $-{ }^{a}$ & $>2$ & 56.00 & $-{ }^{a}$ & [45] \\
\hline $\begin{array}{l}\text { Schiff-base-p-tert butyl- } \\
\text { calix[4]arene. }\end{array}$ & $1.0 \times 10^{-5}-1.0 \times 10^{-1}$ & $6.3 \times 10^{-6}$ & $1.0-6.0$ & 58.90 & 30 & [32] \\
\hline Calix[4]arene. & $1.0 \times 10^{-1}-1.0 \times 10^{-4}$ & $1.0 \times 10^{-4}$ & $-{ }^{a}$ & 50.01 & 3 & {$[46]$} \\
\hline $\begin{array}{l}\text { Schiff-baseN,N'-Bis(pyridine- } \\
\text { 2-Ylmethylene)benzene-1,2- } \\
\text { diamine. }\end{array}$ & $1.0 \times 10^{-7}-1.0 \times 10^{-1}$ & $-{ }^{a}$ & $3.0-8.0$ & 58.60 & 10 & {$[47]$} \\
\hline Isoquinoline-1, 3-diones & $5.0 \times 10^{-6}-1.0 \times 10^{-1}$ & $5.83 \times 10^{-6}$ & $1.0-5.5$ & 58.44 & $<12$ & This work \\
\hline
\end{tabular}

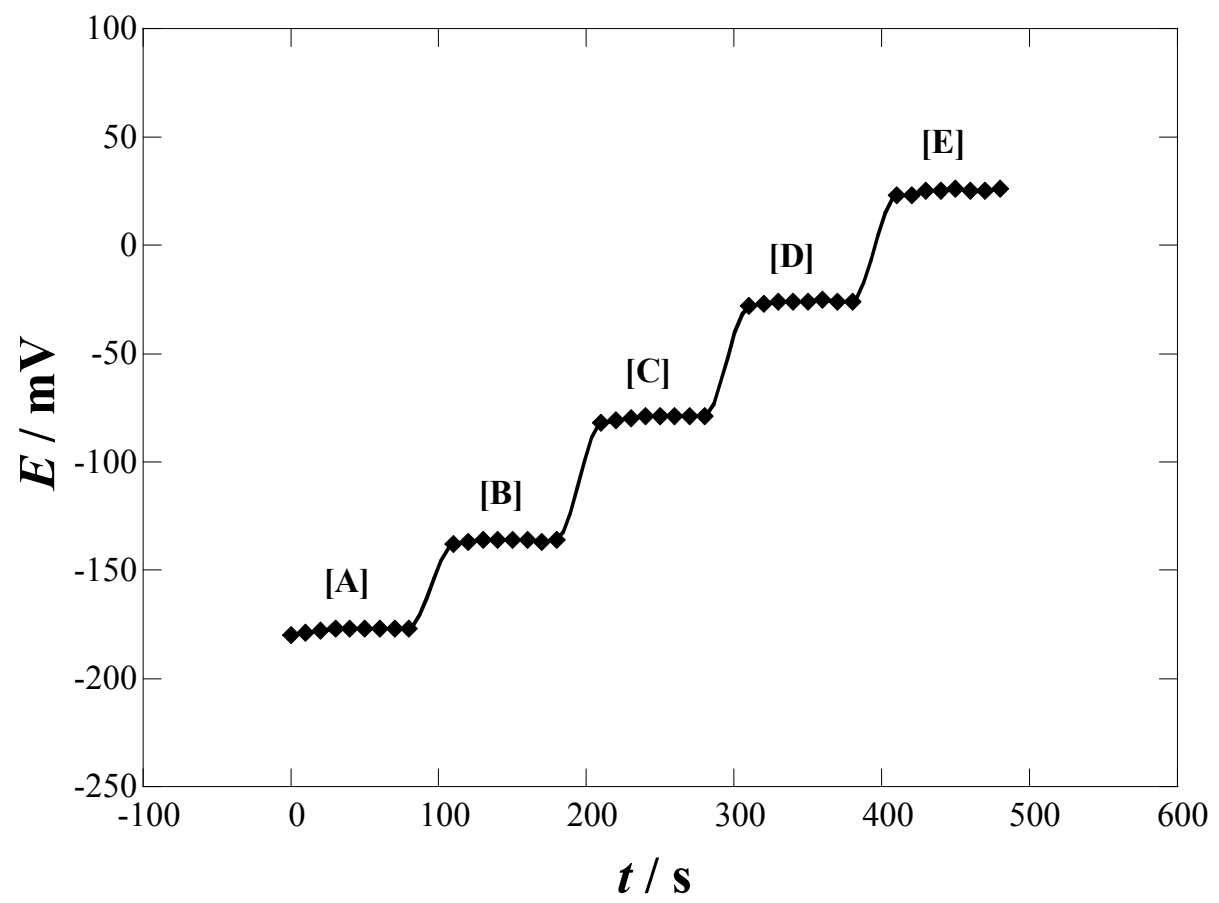

Figure 5. Response time of silver(I) ion selective electrode PME-1, based on isoquinoline-1,3-dione receptor I for step changes in concentration of silver(I) ion. (A) $1.0 \times 10^{-5} \mathrm{M}(B) 1.0 \times 10^{-4} \mathrm{M}$ (C) $1.0 \times 10^{-3} \mathrm{M}(D) 1.0 \times 10^{-2} \mathrm{M}(\mathrm{E}) 1.0 \times 10^{-1} \mathrm{M}$.

\subsection{Electrode selectivity}

The most important characteristic of any ion-selective sensor is its response to the primary ions (A) in the presence of the secondary ions (B) in the solution, which is expressed in terms of the 
potentiometric selectivity coefficients $\left(K_{\mathrm{A}, \mathrm{B}}^{\mathrm{pot}}\right)$. In the present work the selectivity coefficients $\left(\log K_{\mathrm{A}, \mathrm{B}}^{\mathrm{pot}}\right)$ were determined using fixed interference method (FIM) based on the semi empirical Nikolsky-Eisenman equation [48]. In FIM, the selectivity coefficient was evaluated from potential measurements in solutions containing a fixed concentration of interfering cation $\left(1.0 \times 10^{-2} \mathrm{M}\right)$ and varying amount of silver(I) ions. The potential values obtained are plotted versus the activity of the primary silver(I) ions. The potentiometric selectivity coefficients for proposed silver(I) ion selective electrodes PMEs 1-4 were evaluated by FIM as shown in Figure 6. Comparing selectivity data of polymeric membranes PMEs 1-4, it has been found that the $\log K_{\mathrm{Ag}^{+}, \mathrm{B}}^{\mathrm{pot}}$ values for most of the secondary ions are better in case corresponding to PME-1. As seen from Fig. 6 the silver(I) ion electrode PME-1 is significantly more selective to silver(I) ions over all the interfering ions. Although, the selectivity coefficient value for mercury(II) ion is higher than the values for other secondary metal ions ( $\log K_{\mathrm{Ag}^{+}, \mathrm{Hg}^{2+}}^{\mathrm{pot}}=-2.81$ ) still, it has been found that a mercury(II) ion does not interfere in the normal functioning of the proposed silver(I) ion selective electrode PME-1. Moreover, it is found that most of the studied cations such as $\mathrm{K}^{+}, \mathrm{Zn}^{2+}, \mathrm{Fe}^{3+}, \mathrm{Cu}^{2+}, \mathrm{Co}^{2+}, \mathrm{Pb}^{2+}, \mathrm{NH}_{4}^{+}$, $\mathrm{Al}^{3+}, \mathrm{Mg}^{2+}, \mathrm{Na}^{+}, \mathrm{Li}^{+}$and $\mathrm{Cd}^{2+}$ would not cause any interference in determination of silver ions, even if present in large amount.

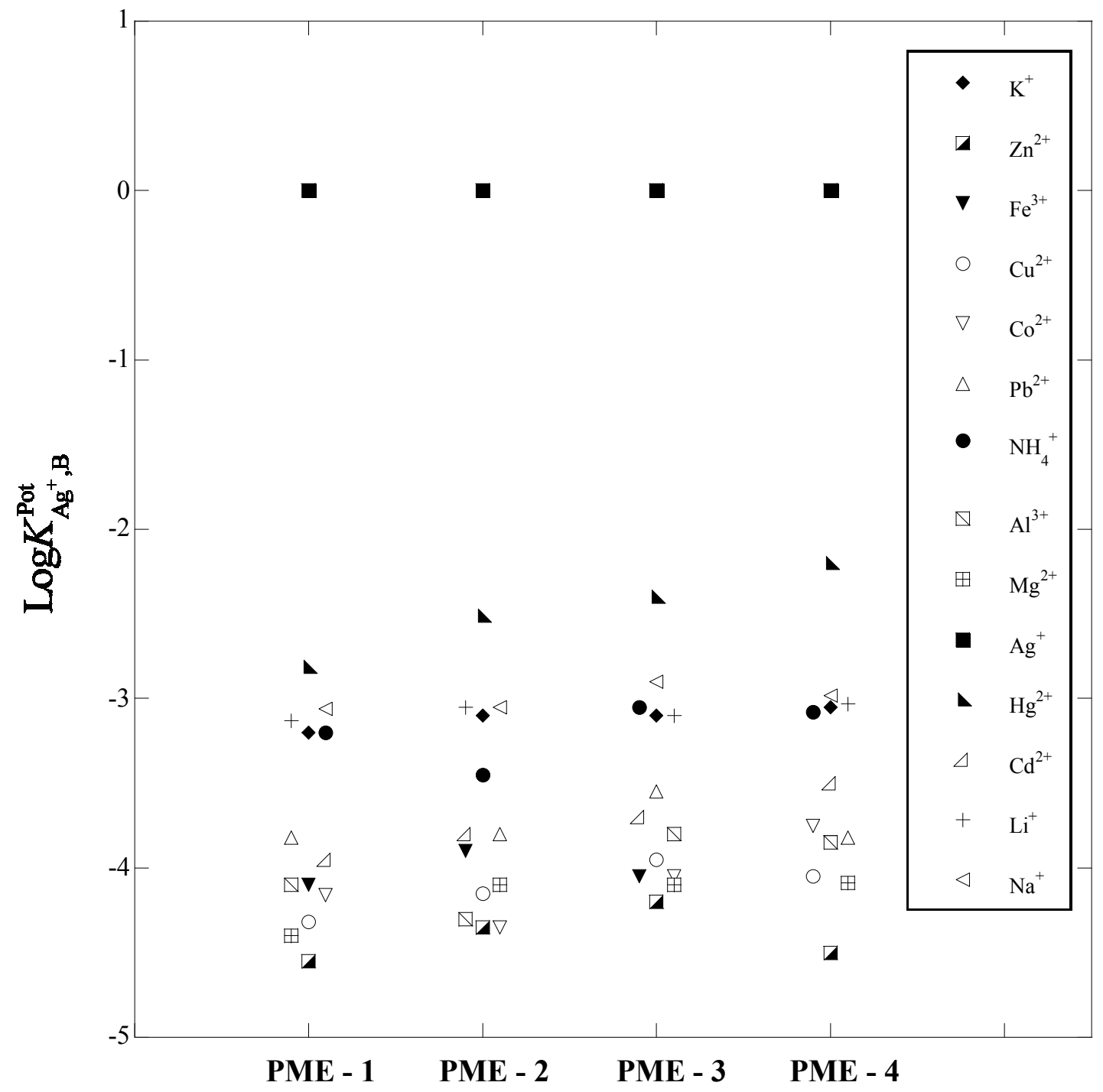

Figure 6. Selectivity of silver(I) ion sensors based on isoquinoline-1,3-dione receptors I-IV 


\section{Analytical application}

The optimized proposed polymeric membrane sensor PME-1 was found to work well under laboratory conditions. Practical utility of the proposed sensors was tested by using them as indicator electrode for potentiometric titration of silver solution $\left(1.0 \times 10^{-2} \mathrm{M}\right)$ with sodium chloride solution $\left(1.0 \times 10^{-2} \mathrm{M}\right)$ as shown in Fig.7. The plot is of sigmoidal shape and the inflexion point of the plot corresponds to 1:1 stoichiometry of the $\mathrm{AgCl}$ precipitation. Therefore, the end point and the amount of silver(I) ions in the solution can be accurately determined by extrapolation of the three linear portions of the titration plot. Also, PME-1 was employed for the quantitative determination of silver(I) ion content in synthetic water (1 and 2), silver foil (3) and dental amalgam (4) samples. In case of silver foil, the sample was prepared by desolving it in diluted nitric acid ( $3 \mathrm{ml}$ of double distilled water and $5 \mathrm{ml}$ of conc. $\mathrm{HNO}_{3}$ ), and then diluted to $100 \mathrm{ml}$ by adding double distilled water. Silver(I) ion content in these samples was also determined volumetrically. The results summarized in Table 3 make it clear that both of these methods of analysis give compatible results providing the practical significance of proposed electrode.

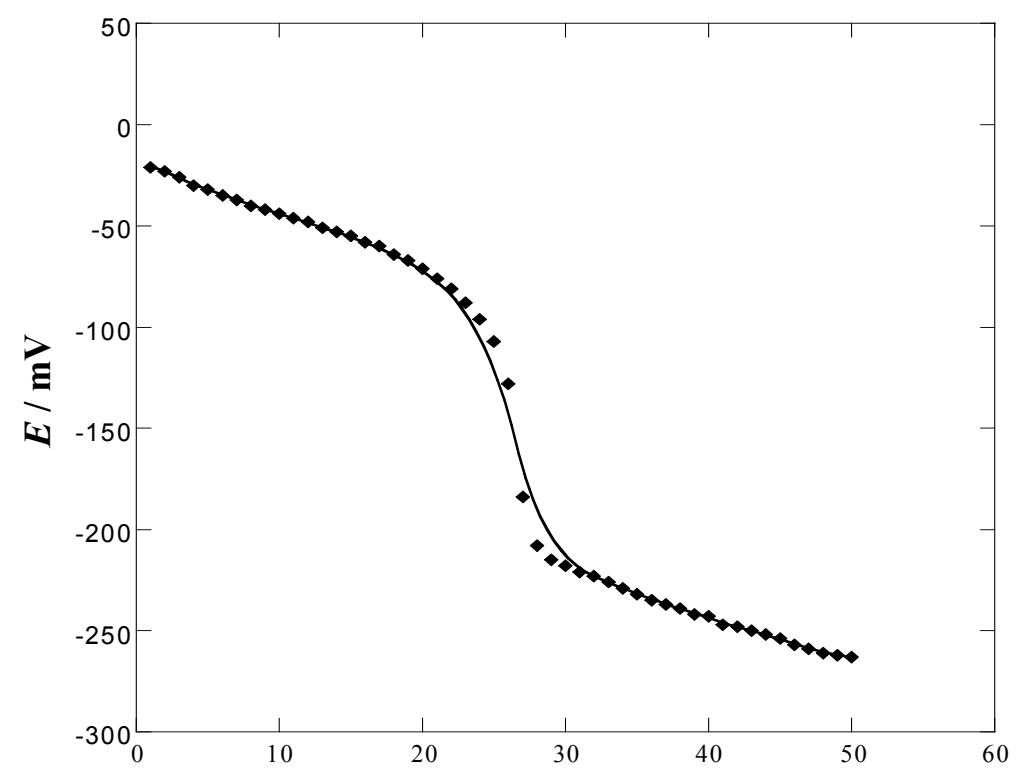

Volume of NaCl solution added, $\mathrm{mL}$

Figure 7. Potentiometric titration of $1.0 \times 10^{-2} \mathrm{M}$ silver(I) solution with $1.0 \times 10^{-2} \mathrm{M} \mathrm{NaCl}$ using PME-1, based on isoquinoline-1,3-dione receptor I

Table 3. Estimation of silver(I) ion content in synthetic water, silver foil and dental amalgam samples

\begin{tabular}{|l|c|c|c|}
\hline \multirow{2}{*}{\multicolumn{1}{|c|}{ Sample }} & \multicolumn{3}{|c|}{ Silver content, M } \\
\cline { 2 - 4 } & Volumetric method & Estimated using PME-I & Compatibility, \% \\
\hline Synthetic Water (1) & $3.72 \times 10^{-3} \mathrm{M}$ & $3.86 \times 10^{-3} \mathrm{M}$ & 103.76 \\
\hline Synthetic Water (2) & $6.69 \times 10^{-4} \mathrm{M}$ & $6.58 \times 10^{-4} \mathrm{M}$ & 98.36 \\
\hline Silver foil (3) & $9.13 \times 10^{-3} \mathrm{M}$ & $9.23 \times 10^{-3} \mathrm{M}$ & 98.91 \\
\hline Dental amalgam(4) & $1.67 \times 10^{-2} \mathrm{M}$ & $1.61 \times 10^{-2} \mathrm{M}$ & 96.41 \\
\hline
\end{tabular}




\section{Conclusion}

Isoquinoline-1,3-dione based receptor I has been found to be novel carrier of silver(I) ions in the PVC based polymeric membrane PME-1. The main advantage of the electrode is the simplicity of construction. It has good response properties and performance, with Nernstian response (58.44 $\mathrm{mV} /$ decade) in the concentration range of the $1.0 \times 10^{-1} \mathrm{M}$ to $5.0 \times 10^{-6} \mathrm{M}$ and detection limit of $5.83 \times 10^{-6} \mathrm{M}$. The sensors have working $\mathrm{pH}$ range of 1.0 to 5.5 with fast response time of less than 12 seconds. The selectivity coefficient indicated that PME-1 sensor is significantly selective to silver(I) ion over many different secondary ions. Even mercury(II) ions were not found to interfere in normal functioning of the proposed PVC membrane PME-1. Additionally, the life time of this electrode longer than three months could be of importance as well. The electrode was successfully applied as an indicator electrode for potentiometric titration of silver(I) ion solution against sodium chloride solution and it can be used for determination of silver(I) ion content in different real samples.

Acknowledgements: This paper was financially supported by the Council of Scientific and Industrial Research (CSIR), New Delhi as a part of project (01)2469/11/EMR-II. One of us AK is thankful to CSIR for the award of Junior Research Fellow (JRF).

\section{References}

[1] E. Malinowska, Z. Brzozka, K. Kasiura, R. J. M. Egberink, D. N.Reinhoudt, Anal. Chim. Acta 298 (2004) 810-817.

[2] L. Chen, H. Ju, X. Zeng, X. He, Z. Zhang, Anal. Chim. Acta 437 (2001) 191-197.

[3] C. Z. Lai, M. A. Fierke, R. C. D. Costa, J. A. Gladysz, A. Stein, P. Buhlmann. Anal. Chem. 82 (2010) 7634-7640.

[4] P. L. Drake, K. J. Hazelwood, Ann. Occup. Hyg. 49 (2005) 575-585.

[5] T. Wang, X. Jai, J. Wu, J. Pharma. Biomed. Anal. 33 (2003) 639-646.

[6] X. J. Yang, R. Foley, G. K. C. Low, Analyst 127 (2001) 505-507.

[7] X. Liu, W. Li, Q. Shen, Z. Nie, M. Guo, Y. Han, W. Liu, S. Yao, Talanta 85 (2011) 1603-1608.

[8] M. Krachler, C. Mohl, H. Emons, W. Shotyk, Spectrochim. Acta 57 (2002) 1277-1289.

[9] P. B. Barrera, A. M. Pineiro, A. B. Barrera, Talanta 43 (1996) 35-44.

[10] S. Dadfarnia, A. M. H. Shabani, M. Gohari, Talanta 64 (2007) 682-687.

[11] E. Bakker, P. Buhlmann, E. Pretsch, Electroanalysis 11 (1999) 915-933

[12] E. Bakker, D. Diamond, A. Lewenstam, E. Pretsch, Anal. Chim. Acta 393 (2001) 191-197

[13] E. Bakker, E. Pretsch, P. Buhlmann, Anal. Chem. 72 (2000) 1127-1133.

[14] E. Bakker, P. Buhlmann, E. Pretsch, Chem. Rev. 97 (1997) 3083-3132.

[15] S. Shahrokhian, A. Hamzehloei, M. Bagherzadeh, Anal. Chem. 74 (2002) 3312-3320.

[16] Z. Szigeti, A. Malon, T. Vigassy, V. Csokai, A. Grun, K. Wygladacz, N. Y. C. Xu, V. J. Chebny, I. Bitter, R. Rathore, E. Bakker, E. Pretsch, Anal. Chim. Acta 572 (2006) 1-10.

[17] A. Ceresa, A. Radu, S. Peper, E. Bakker, E. Pretsch, Anal. Chem. 67 (1995) 1654-1660.

[18] A. Malon, T. Vigassy, E. Bakker, E. Pretsch, J. Am. Chem. Soc. 128 (2006) 8154-8155.

[19] R. S. Hutchins, L. G. Bachas, Anal. Chem. 67 (1995) 1654-1660.

[20] A. Ceresa, E. Bakker, B. Hattendorf, D. Gunther, E. Pretsch, Anal. Chem. 73 (2001) 343-351.

[21] A. Radu, M. T. Diaz, E. Bakker, Anal. Chem. 75 (2003) 6922-6931.

[22] M. Shamsipur, M. Javanbakht, V. Lippolis, A. Garau, G. D. Filippo, M. R. Ganjali, A. Yari, Anal. Chim. Acta 462 (2002) 225-234.

[23] Y. Liu, B. T. Zhao, L. Chen, X. He, Microchem. J. 65 (2000) 75-79.

[24] L. Chen, X. He, B. T. Zhao, Y. Liu, Anal. Chim. Acta 417 (2000) 51-56. 
[25] S. M. Lim, H. J. Chung, K. J. Paeng, C. H. Lee, H. N. Choi, W. Y. Lee, Anal. Chim. Acta 453 (2002) 81-88.

[26] A. Malon, A. Radu, W. Qin, Y. Qin, A. Ceresa, M. M. Zurawska, E. Bakker, E. Pretsch, Anal. Chem. 75 (2003) 3865-3871.

[27] S. S. Lee, M. K. Ahn, S. B. Park, Analyst 123 (1998) 383-386.

[28] R. K. Mahajan, M. Kumar, V. Sharma, I. Kaur, Analyst 126 (2001) 505-507.

[29] M. Kumar, R. K. Mahajan, V. Sharma, H. Singh, N. Sharma, I. Kaur, Tetrahedron Lett. 42 (2001) 5315-5318.

[30] R. K. Mahajan, I. Kaur, V. Sharma, M. Kumar, Sensors 2 (2002) 417-423.

[31] R. K. Mahajan, I. Kaur, M. Kumar, Sen. Actuators 91 (2003) 26-31.

[32] R. K. Mahajan, I. Kaur, R. Kaur, V. Bhalla, M. Kumar, Bull. Chem. Soc. Jap. 78 (2005) 16351640.

[33] R. K. Mahajan, O. Parkash, Talanta 52 (2000) 691-693.

[34] D. Liu, J. Liu, D. Tian, W. Hong, X. Zhou, J. C. Yu, Anal. Chim. Acta 416 (2000) 139-144.

[35] D. Xu, T. Katsu, Anal. Chim. Acta 443 (2001) 235-240.

[36] R. Raj, V. Mehra, P. Singh, V. Kumar, G. Bhargava, M. P. Mahajan, S. Honda, L. G. M. Slaughter, Eur. J. Org. Chem. 2011 (2011) 2697-2704.

[37] T. Rostazin, E. Bakker, K. Suzuki, W. Simon, Anal. Chim. Acta 280 (1993) 197-206.

[38] P. Gehrig, W. E. Morf, M. Welti, E. Pretsch, W. Simon, Helv. Chim. Acta 73 (1990) 203-212.

[39] R. Eugster, P. M. Gehrig, W. E. Morf, U. E. Spichiger, W. Simon, Anal. Chem. 69 (1991) 22852289.

[40] U. Schaller, E. Bakker, U. E. Spichiger, E. Pretsch, Anal. Chem. 66 (1994) 391-398.

[41] P. Anker, E. Wieland, D. Ammann, R. E. Dohner, R. Asper, W. Simon, Anal. Chem. 53 (1981) 1970-1974.

[42] X. Yang, N. Kumar, H. Chi, D. B. Hibbert, P. W. Alexander, Electroanalysis 9 (1997) 549-553.

[43] D. Ammann, E. Pretsch, W. Simon, E. Lindner, A. Bezegh, E. Pungor, Anal. Chim. Acta 171 (1985) 119-129.

[44] E. Jeong, M. S. Ahmed, H. Jeong, E. Lee, S. Jeon, Bull. Korean Chem. Soc. 32 (2011) 800-804.

[45] L. Chen, X. He, H. Zhang, Y. Liu, X. Hu, Hu, Y. Sheng, Anal. Lett. 34 (2001) 2237-2248.

[46] K. M. O'Connor, G. Svehla, S. J. Harris, M. A. Mckervey, Talanta 39 (1992) 1549-1554.

[47] H. Seo, E. Jeong, M. S. Ahmed, H. K. Lee, S. Jeon, Bull. Korean Chem. Soc. 31 (2010) 16991703.

[48] D. G. Hall, J. Phys. Chem. 100 (1996) 7230-7236.

C 2012 by the authors; licensee IAPC, Zagreb, Croatia. This article is an open-access article distributed under the terms and conditions of the Creative Commons Attribution license (http://creativecommons.org/licenses/by/3.0/) (cc) Er 